\title{
THE EMERGENCE OF “TRUE AND FAIR VIEW” PRINCIPLE IN ACCOUNTING WITH SPECIAL REGARDS TO THE PROVISIONS OF THE HUNGARIAN ACCOUNTING ACT
}

Summary: $\quad$ Accounting is playing an important role in ensuring the optimal operation of business entities. The field itself has a long history within the jurisdiction of different countries, however, its international aspects became more dominant with the emergence of multinational corporations. The aim of the study is to give a brief overview of the proliferation of the "true and fair view" principle, which originated in the Anglo-American accounting rules. The study examines international, European and domestic development of accounting rules. Special mention is also made regarding the provisions of the Hungarian Accounting Act. It can be concluded that we can find a convergence in the development of accounting principles on a worldwide level, owing to the needs of the global economy and the international accounting standards.

Keywords: $\quad$ accounting, investment, accounting standards, law and economics

\section{INTRODUCTION}

Accountancy is a special branch of economics within the larger category of social sciences. Fundamentally, accountancy is a means of documenting, recording, reflection and monitoring of financial processes. It follows the various elements of the changing economic trends and records them separately and in conjunction with each other as well. In its contents, it keeps reflecting the live economic processes applying the categories and notions deducted from them. Though historically known under different names, accountancy is just as old as the separation of economic activities based on the division of labour, and of their growing into distinct entities. ${ }^{1}$

Zoltán Zéman, PhD, Full professor, Head of Business Studies Institute, Szent István University, 2100 Gödöllő, Páter Károly utca 1., Hungary. Email address: zeman.zoltan@gtk.szie.hu. ORCID: http://orcid.org/0000-0003-2504-028X.

1 Paxián, M., Zsiray, K., Az angolszász számvitel fejlődéstörténetének középkori, újkori szakasza, Gazdaság és Társadalom Számviteli különszám (Special issue), Vol. 7, 2015, pp.154-162. 
On the other hand, accounting is not limited to the realm of economics only. For example, accounting and taxation laws are closely intertwined, therefore, the law on taxation of companies plays a dominant role in the preparation of financial statements. We also cannot forget about the importance of accounting in the protecting the interests of creditors and investors. That is why we can find many related rules and provisions in company law and in securities law. Accounting law provisions have an interesting character: while various acts in different jurisdictions may impose their own rules, in many cases internationally accepted accounting standards have been made legally binding.

The aim of this paper is to give an overview of the rules and regulations that markedly influenced the development of the Hungarian accounting law. The first part establishes the importance of accounting in an economic sense, thus setting up the criteria which accounting rules and regulations must meet. The second part deals with different models of accounting rules. Two main models of accounting rules can be identified, one stemming from the Anglo-American traditions and the second one being the Continental European model. This part also aims at giving an overview of the development and the characteristics of major international and national standards in accounting. The third part focuses on accounting rules and regulations in Hungary. Currently, Act 100 of 2000 on Accounting serves as the legal basis for accounting standards with some international standards used as supplements. The goal of this part is to establish the way Hungarian legislators adopted the approaches and principles found in the IFRS standards. The fourth part of the paper concludes the study based on the findings of the aforementioned parts.

\section{ROLE OF ACCOUNTING AND THE POSSIBLE MEANING OF “TRUE AND FAIR VIEW" PRINCIPLE}

The subject of accountancy is to track assets within the enterprise. The change of assets includes: firstly, the whole process of operating (business) activities (purchasing, production, marketing), and secondly, the financial transactions and operations of extraordinary events. Economic events are the elements of operating (business) and other activities which can be expressed by means of some unit of measure. Accountancy, therefore, is an objective accounting and information system, which means the organizational study, quantitative description, measurement, systematic documentation and recording of economic operations (events) embodying the business activity. An express objective of accountancy is an unbiased reflection, monitoring and summary of the results of the processes of the operating (business) and other processes. Accountancy records actual data, by which it reflects the past and the present, however, these data can be utilized with perspectives for the future. Functions of accountancy include exhibiting the assets and protection of equity, and by this, the assessment of the actual and real equity situation of the company. It is a means of company administration and management, which continually provides information for internal and external company analyses, for the evaluation of activities and for the examination of effectiveness; also, it serves as a database foundation for business decisions. 
With this feature, accountancy is more than a tool of registration of past (factual) events. By assisting the analysis and evaluation of present, it helps determine future goals, preparation of decisions and operational (business) plans. The principles of accountancy are determined in accordance with the directives of the European Economic Community and the Council of the European Union, also taking their amendments into consideration. The accounting policy of an enterprise is set up based on the accounting philosophy of the entrepreneur, with regard to the principles, in order to receive a full, true and fair view of the company. The general parts of the accounting policy are:

- the choice of the method of accounting,

- the specification of the system of accounting: the chart of accounts,

- the choice of the method and procedures of valuation of assets and liabilities,

- the choice if the method of depreciation,

- the choice of the form of financial statements and the profit and loss statement,

- determination of the time of preparation of financial statements etc.,

- the preparation of the chart of accounts,

- $\quad$ and the preparation of a document protocol.

Thus, accounting rules and regulations must reflect the policies outlined above. Currently, the most followed principle in accounting is called the "true and fair valuation" principle. While the term itself has never been explicitly defined in any legislation, the general understanding is that "true" means faithfulness of the facts ie. nothing is exaggerated or concealed. "Fair" can be summarised as being free from biases in reporting which may distort the results.

\section{MODELS OF ACCOUNTING RULES}

The literature, taking the national peculiarities into consideration, divides the accounting practices into two basic type models. The division categories appear in the literature under various names. Obviously, this does not mean that some features of either model cannot appear in the other, on the contrary, there are countries where the name "mixed system" is the one that best describes the regulation practice and the resulting accounting practice. In our opinion, the similarities and differences reflect the fundamentals of the theoretical approaches. Several scholars agree that the factors influencing the applied accounting practice include the national culture, the circle of capital investors, miscellaneous influencing factors, national practices of accounting, the system of taxation and legislation. The formation of accounting standards, the factors affecting their introduction, and the hypotheses used to elaborate a given accounting standards were subject of studies in many cases. ${ }^{2}$ This matter was in the core of interest of scholars who, following the profit maximization principle, argued that company executives make their business decisions between accounting alternatives with regard to the question whether applying them would be an economic advantage or disadvantage during the accounting practice.

2 Weil, R., Schipper, K., Francis, J., Financial Accounting an Introduction to Concepts, Methods, and Uses, Cengage Learning, 2013, p. 864 
It is pointed out that the lobbying activity at the regulating bodies has its traces in the process of establishing the accounting standards. Consequently, any accounting regulation which subordinates the possible ways of representations accounts, valuations, to the lobbying activity of various interest carriers (by propagating accounting methods which are economically more advantageous for certain interest groups), may lead to the distortion of the objective view. If we observe global accounting practices in national systems, we can study their effects in terms of macroor micro-economic orientation. Macro-oriented regulation is better known as the continental (European) model, and it focuses on accountancy-related legislation and codified law, whereas micro-oriented regulation is in accordance with common law and is known as Anglo-Saxon or Anglo-American model. In our opinion, the administration system, the philosophy and the willingness of investors and the cooperation of the management and the shareholders are equally determinant in a given national economy. In addition to the extensive legal requirements of disclosure, Anglo-Saxon countries have recently witnessed a certain decline of prudential norms, which is a sign of the secondary regulating power of direct intervention of the authorities besides the primary regulating effect of the market, while in the continental (European) model the primary fund-raiser is the state and government bodies. The word-of-law nature and conservatism of regulation aims at the protection of creditors and at long-term stability of the companies, therefore, the principle of prudence plays a dominant role in accounting regulations. ${ }^{3}$

Table 1. Summary of the main features of the two different accounting models

\begin{tabular}{|l|l|l|}
\hline $\begin{array}{l}\text { Definitive } \\
\text { characteristics }\end{array}$ & Anglo-American model & Continental-European model \\
\hline Legal system & $\begin{array}{l}\text { Common law } \\
\text { Micro-oriented regulation } \\
\text { Limited number of regulations } \\
\text { The regulation focuses remedying various } \\
\text { legal cases }\end{array}$ & $\begin{array}{l}\text { Codified law } \\
\text { Macro-oriented regulation } \\
\text { Regulations within acts of different levels } \\
\text { Binding standards }\end{array}$ \\
\hline $\begin{array}{l}\text { Financing } \\
\text { system }\end{array}$ & $\begin{array}{l}\text { Shareholder dominance } \\
\text { Capital funding through many small } \\
\text { investors is important }\end{array}$ & Dominance of government bodies \\
\hline $\begin{array}{l}\text { Accounting } \\
\text { reporting } \\
\text { system }\end{array}$ & $\begin{array}{l}\text { Shareholder- and investor-oriented re- } \\
\text { porting system } \\
\text { Primary need for reporting in terms of } \\
\text { capital, assets and their changes }\end{array}$ & $\begin{array}{l}\text { Authority-oriented reporting system } \\
\text { Primary need to enforce the principle of } \\
\text { prudence, protects creditors }\end{array}$ \\
\hline $\begin{array}{l}\text { Administration } \\
\text { system }\end{array}$ & $\begin{array}{l}\text { Statement of capital change in sharehol- } \\
\text { ders' equity }\end{array}$ & $\begin{array}{l}\text { Presents adherence to prudential } \\
\text { regulations }\end{array}$ \\
\hline $\begin{array}{l}\text { System of } \\
\text { taxation }\end{array}$ & $\begin{array}{l}\text { Self-reporting system } \\
\text { Link to accountancy is negligible }\end{array}$ & $\begin{array}{l}\text { Multiple links to the system of financial } \\
\text { reporting } \\
\text { Determinant on accountancy in terms of } \\
\text { accounting, valuation and reporting }\end{array}$ \\
\hline Auditing & By auditors and stock exchange & Auditors, fiscal auditors \\
\hline Philosophy & To give a true and fair view. & True, fair, full, legal \\
\hline
\end{tabular}

Source: Own compilation, based on Nobes, C., Parker, R., Comparative International Accounting, Prentice Hall, New York-London, 1995, p. 494. 
The features described above are also determinant on how the two models are macroeconomically related to the economic policy of a given country. The Anglo-American model concentrates on supplying the operators with relevant information, therefore the system of taxation is separate from the accountancy requirements. In contrast, in the Continental (European) model, in many cases, taxation laws determine the mode of accounting and valuation of business transactions and the presentation requirements of reporting. The elaboration and maintenance of international accounting standards is in the hands of the International Accounting Standards Board, seating in London. International Accounting Standards, as in the Anglo-American practice, contain problem-solving, technical regulations. ${ }^{4}$

\subsection{INTERNATIONAL STANDARDS}

There are three main accounting rule units which serve as the basis of the global regulation of accountancy. ${ }^{5}$

The International Accounting Standards Committee (IASC) was founded in 1973 in London by ten countries to elaborate, promote and develop, in the public interest, a single set of high quality, understandable, enforceable financial reporting standards (IAS). The founders were Australia, France, Canada, Germany, Japan, Mexico, the Netherlands, United Kingdom, Ireland and IJSA. IASC was reformed in March 2001; a new constitution was put into effect by the trustees, and a non-profit company the IASC Foundation was established, so that it supervises the work of the International Accounting Standards Board (IASB). The naming of standards was changed from 2001. The standards elaborated by IASC are called International Accounting Standards (IAS), while those elaborated by IASB are called International Financial Reporting Standards (IFRS). The objectives of IASC, according to the revised constitution are:

- "to develop, in the public interest, a single set of high quality, understandable, enforceable and globally accepted financial reporting standards [...that] require high quality, transparent and comparable information in financial statements and other financial reporting to help investors, other participants in the world's capital markets and other users of financial information make economic decisions.

- to promote the use and rigorous application of those standards

- to promote the convergence of national accounting standards and IFRS”.

2. The regulation of US GAAP is a well-established system, which is the national regulation of the USA but it also has cross-border influence.

3. A Community level regulation of accounting has not begun in the EU until the 1970s. Its precedent was the first company law directive (68/151/EEC), which regulated the disclosure

4 Asbaugh, P., Pincus, M., Domestic Accounting Standards, International Accounting Standards and the Predictability of Earnings, Journal of Accounting Research, Vol. 39, No. 3, 2001, pp. 417-434.

5 IFAC, Competency Profiles for Management Accounting Practice and Probationers, International Federation of Accountants, New York, 2002; IFAC, International Management Accounting Practice Statement: Management Accounting Concepts, International Federation of Accountants New York, 1998. 
requirements of corporate enterprises, regarding the risk of establishment until it had been repealed in 2009.

\subsection{THE DEVELOPMENT OF ACCOUNTING RULES IN KEY COUNTRIES}

This section aims at summarising the approach and the key movements in the development of accounting rules and laws in countries that served as a major influence on accounting. As we will see, we can identify a trend of convergence towards the "true and fair" valuation principle in countries which previously based their accounting laws on other principles.

The USA GAAP is rules based, instead of being principles based. The development of accounting rules in the USA is highly intertwined with securities legislation. In 1911 the first "blue sky law" enacted which regulated securities transactions in Kansas. The next milestone in accounting legislation was in $1934 .{ }^{6}$ As a part of Franklin D. Roosevelt's New Deal legislation package, the Securities Exchange Act established the Securities Exchange Commission (SEC), which was tasked with regulating the listing and the accounting criteria for listed stock corporations. As a result to SEC's rulemaking, the American Institute of Accountants (AIA) reorganised its Committee of Accounting Procedure (CAP) in 1939, in order to make their organisation more responsive to the changes in accounting rules. In 1953 the accounting standards called "Generally Accepted Accounting Principles" (GAAP) was established. Between 1959-1973 the Accounting Principles Boards (APB) acted as the main body for setting standards. From 1973 the Financial Accounting Standards Board (FASB) had been acting as the main organization for establishing and improving accounting standards. ${ }^{7}$ The accounting industry was self-regulated until the adoption of the Sarbanes-Oxley Act in 2002 which established the Public Company Accounting Oversight Board (PCAOB) placing the accounting profession under governmental oversight. This was a reaction to the abuses in the accounting profession which culminated in the events of major scandals, such as Enron or Worldcom. ${ }^{8}$

It must be emphasized that corporate law and accounting law has two levels in the United States. On one hand, federal laws apply to certain aspects, on the other hand, state laws are applicable. ${ }^{9}$ State laws were the driving forces behind some of the changes outlined in the table above. Two pillars can be highlighted in the international development ${ }^{10}$ which firstly put emphasis on financial statements, then secondly on other financial reports. This was due

6 Kecskés, A., A kereskedelmi jog régi professzorai Pécsen: Bozóky Géza és Rudolf Lóránt, in: Pécsi jogászprofesszorok emlékezete (1923-2008), Pécs, 2008, p. 250.

7 Securities and Exchange Commission Historical Society, Timeline. http://www.sechistorical.org/museum/ timeline/1950timeline.php. Accessed 18 June 2018.

8 Kecskés, A., The Sarbanes-Oxley Act from a Legislative Viewpoint, Theory and Practice of Legislation Vol. 4, No. 1, 2016, pp. 1-17.

9 Within the United States, the corporate law of Delaware plays an important role. This was due to two processes. On one hand, the corporate law of the state favors the directors which in turn results in more incorporations in Delaware state. As a result, the laws of the other states are highly influenced by Delaware law. Owing to its importance, the so-called "Delaware-effect" became the subject of many corporate law researches. The correlation between the incorporations and application of the law warrants a complex approach. Halász V., Kecskés A., Stock Corporations: A Guide to Initial Public Offerings, Corporate Governance and Hostile Takeovers, HVG-ORAC-LexisNexis, Budapest-Bécs, 2013.

10 Ball, R., International Financial Reporting Standards (IFRS): Pros and Cons for Investors, Journal Accounting and Business Research, Vol. 36, No. 1, 2006, pp. 5-27. 
to the settlements of the increasing amount of financial investments and the emergence of speculative investments. ${ }^{11}$

The United Kingdom follows the "true and fair view" principle, which was incorporated into the Companies Act 1947 for the first time; however, no definition was given. Thus, finding the meaning of the term had been left to the courts and the profession. ${ }^{12}$ In their joint opinion, Hoffman and Arden argued was that no legal definition was required, as the meaning could be understood in plain English. ${ }^{13}$ In an expert opinion for the Argyll case, ${ }^{14}$ Professor Arnold defined "true and fair" as the accounts must be "relevant, objective and free from bias". ${ }^{15}$ Meanwhile, McGee argued that firstly, a legal test is needed for the substance of the principle, secondly, there might be more than one "true and fair view" as the language of the Companies Act 1985 used an indefinite article. The Companies Act 2006 also retained the "true and fair view" principle in section 393, but the indefinite article had been dropped from the language, possibly meaning the legislators only considered one "true and fair view".

The development of accounting rules was constant, however. Beginning from the mid1960s attempts were made at harmonising accounting regulations by drawing up a single standard. In 1970 the Accounting Standards Steering Committee (ASSC) was established which renamed itself in to Accounting Standards Committee (ASC) in 1976. An important milestone in accounting legislation of the UK was the Companies Act 1985 which not only contained the format and the content of the main parts of the report, but also the valuation procedures. In 1990 the Financial Reporting Council (FRC) and the Accounting Standard Board (ASB) became the governing bodies of regulating by setting financial standards.

The German principle of accounting until 1985 required true-accurate-complete valuations in the accounts. After 1985 the true and fair valuation principle had been adopted due to the implementation of European Directives regarding accounting. The origins for German accounting could be traced back to the end of 18th century when compilations of commercial laws containing the accounting regulations had been made. Even the Prussian Civil Code, Allgemeines Landrecht (ALR) enacted in 1794, contained provisions on bookkeeping. In 1937 the Mandatory Imperial Account Framework became the standard for accounting, which was codified in the Stock Corporation Law (Aktiengesetz, AktG) and which saw no changes until 1965. ${ }^{16}$ In 1985 the Bilanzrichtlinie-Gesetz (balance sheet-directive act) was enacted which became a part of the commercial code (Handelsgesetzbuch, HGB). The Act brought in two major changes: firstly, by prescribing a unified accounting system for operational and business use; secondly, the focus of accounting shifted from taxation purposes to the protection of investors and creditors. In 1999 the Deutsches Rechnungslegungs Standards Committee,

11 Edwards, J.R., A History of Financial Accounting, Routledge Publisher USA, New York, 2014, p. 341.

12 It is worth mentioning that even John Austin found courts to be an important source of law. See: Kecskés, A., Inside and Outside the Province of Jurisprudence, Rechtstheorie Vol. 46, No. 4, 2015, pp. 465-479.

13 McGee, A., The True and Fair View Debate, The Modern Law Review, Vol. 54, No. 6, 1991, pp. 874-888, p. 878

14 Hoffmann, L., Arden, M., Legal Opinion Obtained by Accounting Standards Committee of True and Fair View, With Particular Reference to the Role of Accounting Standards, 1983. https://www.frc.org.uk/ getattachment/afba0aa1-04fa-492a-beab-35918af6d97e/T-FOpinon-13-September-1983.pdf. Accessed 18 June 2018.

16 Accountants Germany, History of German Accounting Standards - When Did it Start and How Did it Go. https://www. accountantsgermany.com/wiki/german-gaap-history-1/. Accessed 18 June 2018. 
the German Accounting Standards Committee (DRSC) had been established. The role of the Committee is to adopt standards concerning corporate groups, having been authorized by laws. The other main body for developing accounting standards and procedures is Institut der Wirtschaftsprüfer in Deutschland e.V. (Institute of Public Auditors in Germany, Incorporated Association) (IDW).

The main approach towards accounting in France could be summarised with regularity and sincerity until 1985; afterwards the true and fair view approach was adopted. Beginning from the early 1940s the Code de Commerce (Commercial Code) prescribes accounting and financial reporting. In 1947 the Plan Comptable Général (PCG) the generally accepted accounting principles in France was created, which became a mandatory framework law. ${ }^{17}$ It incorporated the operational and business accounting and the drafting of reports. The accounting act in France was enacted in 1998, when the PCG rules were reworked. In the same year the Comite de la Réglementation Comptable (Accounting Rules Committee CRC) was formed which, along with the Conseil National de la Comptabilité (National Accounting Council - $\mathrm{CNC}$ ), were replaced by the Autorité des Normes Comptables (Accounting Standards Authority ANC) in 2010.

\subsection{EUROPEAN LEGISLATION}

In Europe, accounting rules varied between countries which made the comparison of undertakings much harder. Thus, the need for harmonising the content and the methods of accounting became an important issue, in order to ensure the comparability of the performance of undertakings between the member states, thus dismantling the obstacles that hindered the progress towards the unified (later on: single) market.

The first milestone in European accounting legislation was the $1^{\text {st }}$ Company Law Directive (Directive 68/151/EEC) which set out to harmonise rules on disclosure as a way of safeguarding the interests of the members of companies and other parties. In 1978 the $4^{\text {th }}$ Company Law Directive (78/660/EEC) was adopted on the annual account of certain type of companies, with the aim of harmonising the content of accounts by setting out the standard information which the accountancy laws of member states were required to ask for. The $4^{\text {th }}$ Company Law Directive had been drafted on the principle of "true and fair" valuation, at the insistence of the United Kingdom, which affected countries following different principles. ${ }^{18}$ The scope of the directive mainly concerned public or private companies with limited liability due to their economic importance and the potential for abusing limited liability. Another important directive was the $7^{\text {th }}$ company law directive in 1983 (83/349/EEC) which aimed at harmonising the consolidated accounts for corporate groups. In 1984, the EEC harmonised the requirements for auditors with the Directive 84/253/EEC, also known as the $8^{\text {th }}$ Company Law Directive. By harmonising the content and the qualification requirement for auditing and accountancy, the European Commission hoped to achieve cross-country comparability, thus further facilitating intra-EU investments.

17 Zeff, S., The Evolution of the IASC into IASB, and the Challenges it Faces, The Accounting Review, Vol. 87, No. 3, 2012, pp. 807-837, p. 808. 
Another major milestone in European Accounting legislation was the adoption of Regulation 1606/2002/EC, which made the IAS and the IFRS part of European law. This was the culmination of a longer process, as on 13 June 2000 the European Commission proposed that publicly traded companies should prepare their reports according to a single set of international standards. ${ }^{19}$ The Regulation also aimed at further strengthening the "true and fair view" principle within the European Union to achieve reports that are useful to the users. ${ }^{20}$

In 2006, Directive 2006/43/EC on statutory audits of annual accounts and consolidated accounts had been adopted, which amended the $4^{\text {th }}$ and the $7^{\text {th }}$ Company Law Directives and also repealing the $8^{\text {th }}$ Company Law Directive. The main reason for the enacting the Directive was to further harmonise the statutory audit requirements. However, the full-harmonisation was out of the question at the time, as evidenced by the paragraph 5 of the Preamble.

An important development recently in European accounting law was the adoption of Regulation 2013/34/EU which was important for two reasons. Firstly, the Regulation superseded the $4^{\text {th }}$ and the $7^{\text {th }}$ Company Law Directives by repealing them and by also incorporating their contents (the $8^{\text {th }}$ Company Law Directive had been repealed earlier in 2006). Secondly, since it became a Regulation instead of a Directive, the provisions on accounting became directly applicable without requiring further implementation. This showed a greater degree of harmonisation of accounting laws than before. This legislative programme falls in line with the plans of the Commission which aimed at fostering the Single Market and the Capital Markets Union. This effort is also aided by the new directive on company law (2017/1132/EU) which, amongst many things, updated the disclosure rule requirements while also repealing outdated company law directives.

\section{THE DEVELOPMENT OF ACCOUNTING RULES AND REGULATIONS IN HUNGARY}

Having reviewed the international regulation practices it can be argued that the primary requirements of compilation of the financial statements include publishing of information, presentation of assets and the presentation of the elements of financial and income situation, which the Hungarian regulation of accountancy is presently well suited to.

The objective of establishing the Hungarian accounting standards was to prepare a unified accounting practice, by bringing the Hungarian accounting legislation, the accounting regulations of the European Union and the International Financial Reporting Standards in accordance. National legislation is not replaced by standards-based regulation, but it includes, by supplementing it, detailed regulations, methods and procedures. The international development of accounting indicates the emergence of national and international standards.

Reporting under unified standards helps the investors to be informed with clarity, so member states in the Central European region have broadened the circle of companies which are

19 Regulation 1606/2002/EC Preamble paragraph 6. 
obliged to IFRS-compliant reporting. The enterprises facing the phenomenon of globalization experienced accounting difficulties in certain areas. Firstly, when they tried to compare enterprises in different countries, in terms of establishing business and investment connections; secondly, at the compilation of consolidated statements of multinational enterprise groups, and thirdly, on the creation at stock exchanges of other countries.

In Hungary, the main national regulations of valuation at fair rate are contained in Section 59/A to 68 of Act C of 2000 on Accounting. According to Section 59/A, paragraph (1), companies using double-entry bookkeeping may introduce, by decision to be fixed in their accounting policies, a system of fair valuation - specified in this Section and in Sections 59/B-59/F - for the financial instruments defined in accordance with what is contained in Subsections (6) and (7). Section 59/A paragraph (3) stipulates that companies using fair valuation may apply the provisions of the Government Decree 250/2000. (XII. 24.) on the Special Provisions Regarding the Annual Accounting and Bookkeeping Obligations of Credit Institutions and Financial Companies that pertain to fair valuation regarding issues that are not regulated in this Section and in Sections 59/B-59/F.

Section 59/F contains provisions on adopting fair valuation system. First of all, switching to the fair valuation system shall be carried out as of the first day of the financial year, according to the rules of reclassification.

According to Section 59/F, paragraph (2), when switching to fair value accounting, the following items shall be carried forward effective as of the day of transfer (first day of the financial year when the transition is carried out):

a) adjustments in the value of financial instruments shown in the balance sheet as held for trading and valuated at fair value, deducted from other expenses on financial transactions, the revaluation of the book value on the day of transfer to market value shown as the asset's valuation difference against other income from financial transactions or other expenses on financial transactions, as appropriate;

b) the market value after the revaluation of marketable debt securities and investments in equity instruments in another independent entity shown under fixed assets and valuated by fair value accounting that - if in excess of the historical cost (original cost or purchase price) - the amount of impairment loss up to the adjusted historical cost (original cost or purchase price) or up to the historical cost (original cost or purchase price) with any repayment deducted if it pertains to a receivable shown under the costs of financial operations and other operating charges, respectively, and the asset's valuation difference that is in excess shown against the fair value reserve;

c) in connection with derivatives still open on the balance sheet date that are not mentioned in Paragraph d), the amount of forecasted profit or loss claimed under prepayments and accrued income and accruals and deferred income, the provisions terminated shown against other income from financial transactions or other expenses on financial transactions, or other interest and similar income (received or due) or interest payable and similar charges, other income, as appropriate, and the revaluation of the transactions - the amount of forecasted profit or loss claimed whether or not for hedging purposes and whether shown under accounts receivable or accounts payable - in the amount of the valuation difference (positive or negative) of the derivative transactions 
in question against other income from financial transactions or other expenses on financial transactions, or other interest and similar income (received or due) or interest payable and similar charges;

d) in connection with cash-flow hedges and hedges of net investments in nonresident business associations that are still open on the balance sheet date, the amount of forecasted profit or loss claimed under prepayments and accrued income and accruals and deferred income when terminated against other income from financial transactions or other expenses on financial transactions, and the revaluation of the transactions - the amount of forecasted profit or loss claimed - in the amount of the valuation difference (positive or negative) of the derivative transactions in question against the fair value reserve.

Paragraph (3) stipulates that switching from fair valuation to historical cost (original cost or purchase price) valuation is permitted on the balance sheet date according to the general rules of reclassification. Upon switching, the valuation differences already claimed shall be terminated by settling the accounts of the financial instruments to which they pertain against the result or the fair value reserve, as appropriate, and by the accounting of justified impairment losses, accruals and deferrals, and provisions in accordance with the general rules governing the system of historical cost (original cost or purchase price) valuation.

The primary legislative will in Hungary was the gradual adaptation of the international rules of financial instruments, as the relevant standards were under fundamental reworking and Hungary had a more closely intertwined accounting and taxation practice, and as executive authorities were not yet prepared to a full conversion. IAS standard 1 divides financial reports into the following types: balance sheet, income statement (which presents any changes in equity and any changes in capital which are unrelated to shareholders), cash flow statement, accounting policy, and the supplement of other explanatory notes. Accounting standards in the global economy have elements with strong influence on accounting policies. The efforts of the participants of global economy to ensure unity of accounting to provide comparable financial statements are influential on the standards established. It is essential for the regulation of those small and medium-sized enterprises which do not fall under IFRS reporting obligation, to have a system of rules based on professional grounds. Theoretically, the anomaly of uncertainty in the preparation of the accounting statements is dissolved by the introduction of standards. ${ }^{21}$ The introduction of international standards is in process in Hungary, though their home elaboration is not yet finished. The Hungarian Accounting Act includes provisions about accounting standardization, also providing its limits (Section 114/A to 114/H). As it is known, only companies with stock exchange presence are obliged to prepare IFRS-compliant annual report in Hungary. Considering that only a negligible proportion of Hungarian companies have stock exchange presence, IFRS compliant reporting is only required of a tiny segment of companies. Those enterprises which prepare non-IFRS-compliant statements take the principles within the standards into account. ${ }^{22}$

21 Abdel-Kader, M., Luther, R., IFAC's Conception of the Evolution of Management Accounting, Advances in Management Accounting, Vol. 15, No. 1, 2006, p. 244.

22 Laux, C., Financial Instruments, Financial Reporting, and Financial Stability, Journal Accounting and Business Research, Vol. 42, No. 3, 2012, pp. 239-260. 


\section{CONCLUSION}

The aim of the paper was to showcase the worldwide adoption of the "true and fair view" principle. It can be concluded that it is rooted in the English accounting laws and accounting practice which became accepted worldwide due to the IFRS and the EU harmonisation of accounting laws. The main objective of standardization in Hungary was the harmonization with international accounting standards (IAS/IFRS). Our research in this regard, is focused on accounting policy, and this is the segment which is to be analysed to receive a full view. IAS 8 Accounting Policies, Changes in Accounting Estimates and Errors, being in effect in Hungary, is most influential and determinant on the main elements in our financial researches. This will, in due course, be replaced by the Hungarian accounting standard, which, being a theoretical conception, is under elaboration. Until it is fully elaborated and introduced on the level of practice, IAS 8 international standard will be determinant in terms of accounting policy. ${ }^{23}$ The objective of the standard is the harmonization of the Hungarian accounting legislation with international financial reporting systems. Accounting policy is the solid choice of rules, regulations and methods founding business decisions that are necessary for the enterprise to meet their obligations under the accounting legislation, with regard to the particularities of the enterprise. The requirements necessary to meet the aforesaid obligations are presented within the framework of the accounting policy. Such factors are the numerical assessment of the accounting entries important/unimportant, significant/insignificant, in terms of valuation. The final goal always must be to ensure a most optimal view of the company to external operators.

\section{REFERENCES}

1. Abdel-Kader, M., Luther, R., IFAC's Conception of the Evolution of Management Accounting, Advances in Management Accounting, Vol. 15, No. 1, 2006, pp. 229-247.

2. Asbaugh, P., Pincus, M., Domestic Accounting Standards, International Accounting Standards. and the predictability of earnings, Journal of Accounting Research, Vol. 39, No. 3, 2001, pp. 417-434.

3. Ball, R., International Financial Reporting Standards (IFRS): Pros and Cons for Investors, Journal Accounting and Business Research Vol. 36, No. 1, 2006, pp. 5-27.

4. Botzem, S., The Politics of Accounting Regulation - Organizing Transnational Standard Setting in Financial Reporting, Edward Elgar Publisher, Massachusetts, 2012, p. 223.

5. Edwards, J.R., A History of Financial Accounting, Routledge Publisher USA, New York, 2014, p. 341.

6. Halász, V., Kecskés, A., Stock Corporations: A Guide to Initial Public Offerings, Corporate Governance and Hostile Takeovers, HVG-ORAC-LexisNexis, Budapest-Bécs, 2013.

7. IFAC, Competency Profiles for Management Accounting Practice and Probationers, International Federation of Accountants, New York, 2002.

8. IFAC, International Management Accounting Practice Statement: Management Accounting Concepts, International Federation of Accountants New York, 1998.

9. Kecskés, A., A kereskedelmi jog régi professzorai Pécsen: Bozóky Géza és Rudolf Lóránt, in: Pécsi jogászprofesszorok emlékezete (1923-2008), Pécs, 2008, pp. 247-260.

23 Botzem, S., The Politics of Accounting Regulation - Organizing Transnational Standard Setting in Financial Reporting, Edward Elgar Publisher, Massachusetts, 2012, p. 223. 
10. Kecskés, A., Inside and Outside the Province of Jurisprudence, Rechtstheorie, Vol. 46, No. 4, 2015, pp. 465-479.

11. Kecskés, A., The Sarbanes-Oxley Act from a Legislative Viewpoint, Theory and Practice of Legislation Vol. 4, No. 1, 2016, pp. 1-17.

12. Laux, C., Financial Instruments, Financial Reporting, and Financial Stability, Journal Accounting and Business Research, Vol. 42, No. 3, 2012, pp. 239-260.

13. McGee, A., The True and Fair View Debate, The Modern Law Review, Vol. 54, No. 6, 1991, pp. 874-888.

14. Nobes, C., Parker, R., Comparative International Accounting, Prentice Hall, New York-London, 1995, p. 494.

15. Paxián, M., Zsiray, K., Az angolszász számvitel fejlödéstörténetének középkori, újkori szakasza, Gazdaság és Társadalom Számviteli különszám, Vol. 7, 2015, pp.154-162.

16. Weil, R.; Schipper, K.; Francis, J., Financial Accounting an Introduction to Concepts, Methods, and Uses, Cengage Learning, 2013, p. 864.

17. Zeff, S., The Evolution of the IASC into IASB, and the Challenges it Faces, The Accounting Review, Vol. 87, No. 3, 2012, pp. 807-837.

\section{LIST OF REGULATIONS, ACTS AND COURT DECISIONS}

1. Act $C$ of 2000 on Accounting Hungarian Gazette 2000/95 pt. 1.

2. Government Decree 250/2000. (XII. 24.) on the Special Provisions Regarding the Annual Accounting and Bookkeeping Obligations of Credit Institutions and Financial Companies Hungarian Gazette 2000/130.

3. Regulation $1606 / 2002 / E C$.

\section{WEBSITE REFERENCES}

1. Accountants Germany, History of German Accounting Standards - When did it Start and how did it go. https://www.accountantsgermany.com/wiki/german-gaap-history-1/. Accessed 18 June 2018.

2. Hoffmann, L., Arden, M., Legal Opinion Obtained by Accounting Standards Committee of True and Fair View, With Particular Reference to the Role of Accounting Standards, 1983. https://www.frc.org.uk/ getattachment/afba0aa1-04fa-492a-beab-35918af6d97e/ T-F -Opinon-13-September-1983.pdf. Accessed 18 June 2018.

3. Securities and Exchange Commission Historical Society, Timeline, http://www.sechistorical.org/ museum/timeline/1950-timeline.php. Accessed 18 June 2018. 


\section{NASTANAK NAČELA "ISTINITOG I POŠTENOG IZVJEŠĆIVANJA" U RAČUNOVODSTVU S POSEBNIM OSVRTOM NA ODREDBE MAĐARSKOG ZAKONA O RAČUNOVODSTVU}

\section{Sažetak}

Računovodstvo ima važnu ulogu u osiguravanju optimalnog poslovanja poslovnih subjekata. Ono ima dugu povijest u različitim zemljama, međutim, nastankom multinacionalnih kompanija njegovi međunarodni aspekti postali su izraženiji. Cilj je rada dati kratak pregled širenja primjene načela "istinitog i poštenog izvješćivanja" koje potječe iz pravila koja se primjenjuju u angloameričkom računovodstvu. U radu se istražuje razvoj međunarodnih, europskih i mađarskih računovodstvenih pravila s posebnim osvrtom na odredbe mađarskog Zakona o računovodstvu. Može se zaključiti da postoji konvergencija u razvoju računovodstvenih načela na svjetskoj razini zbog potreba globalne ekonomije i međunarodnih računovodstvenih standarda.

Ključne riječi: $\quad$ računovodstvo, investicija, računovodstveni standardi, pravo i ekonomija

\section{(c) (1) $\$$}

This work is licensed under a Creative Commons

Attribution-NonCommercial 4.0 International License.

Dr. sc. Zoltán Zéman, redoviti profesor, voditelj Business Studies Institute, Sveučilišta Szent István, 2100 Gödöllő, Páter Károly utca 1., Mađarska. Adresa e-pošte: zeman.zoltan@gtk.szie.hu. ORCID: http://orcid.org/0000-0003-2504-028X. 